\title{
REVISTAMARACANAN
}

Artigos

\section{Da barbárie à memória: imagens urbanas como espaços de resiliência}

\author{
From barbarism to memory: urban images as spaces of resilience
}

Hércules da Silva Xavier Ferreira*

Universidade Federal do Estado do Rio de Janeiro

Rio de Janeiro, Rio de Janeiro, Brasil

\begin{abstract}
Luana Campos**
Instituto do Patrimônio Histórico e Artístico Nacional

Rio de Janeiro, Rio de Janeiro, Brasil

Pedro Gustavo Morgado Clerot ${ }^{* * *}$

Instituto do Patrimônio Histórico e Artístico Nacional Brasília, Distrito Federal, Brasil
\end{abstract}

Recebido em: 14 jan. 2020.

Aprovado em: 11 maio 2020.

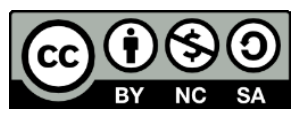

\footnotetext{
* Doutorando em Memória Social pela Universidade Federal do Estado do Rio de Janeiro. Mestre em Preservação do Patrimônio Cultural pelo Instituto do Patrimônio Histórico e Artístico Nacional; Especialista em Produção Cultural pela Universidade Cândido Mendes; graduado em Filosofia pela Universidade Federal do Estado do Rio de Janeiro. (hxferreira@yahoo.com.br)

ORCID iD: https://orcid.org/0000-0002-6147-4563
}

CV Lattes: http://lattes.cnpq.br/4353223388456765

** Professora "recém-doutora" no Mestrado Profissional em Preservação do Patrimônio Cultural do Instituto do
Patrimônio Histórico e Artístico Nacional. Doutora em Quaternário, Materiais e Culturas pela Universidade de
Trás-os-Montes - Alto Douro; Mestra em Arqueologia Pré-histórica e Arte Rupestres pela Universidade Tras-dos-
Montes - Alto Douro; Especialista em Sistema de Informação Geográfica pelo Instituto Politécnico de Tomar;
Especialista em Antropologia Forense pela Universidade de Coimbra; graduada em História pela Universidade
Federal de Mato Grosso do Sul. (Icampos.ms@gmail.com)

ORCID iD: https://orcid.org/0000-0001-5985-1756

CV Lattes: http://lattes.cnpq.br/0977000419665282

\footnotetext{
*** Técnico em Ciências Sociais do Instituto do Patrimônio Histórico e Artístico Nacional. Mestre em Preservação do Patrimônio Cultural pelo Instituto do Patrimônio Histórico e Artístico Nacional; Especialista em Gestão de Políticas Públicas para a Cultura e graduado em História e em Ciências Sociais, com habilitação em Antropologia, pela Universidade de Brasília. (pedroclerot777@gmail.com)

ORCID iD: https://orcid.org/0000-0002-9807-7844

CV Lattes: http://lattes.cnpq.br/2205848875990715
} 


\title{
Resumo
}

Nos anos 1998, 2005 e 2017, ocorreram três mortes criminosas em três espaços próximos entre si, na Zona Sul da cidade do Rio de Janeiro. Três jovens de classe média foram brutalmente assassinados e ganharam homenagens póstumas, de uma escultura e dois grafites respectivamente. E no ano de 2018 a vereadora Marielle Franco foi assassinada, ensejando similar compreensão social e ressignificando o local de ocorrência do crime, e muitos outros, com intervenções artísticas. Tais espaços e seu entorno, assim como tantos outros que pontuam as cidades brasileiras, bem poderiam receber a alcunha de polígono da violência ou circuito da dor, por retratarem pessoas mortas. Diante desta realidade, a pesquisa aqui apresentada trata de uma reflexão analítica à luz dos conceitos de "recolhimento" e "distração" de Walter Benjamin, com a proposta comunicológica de Vilém Flusser, tendo ainda por base a poética da ausência de Fernando Catroga e os estudos culturais sobre a memória de Aleida Assmann, como uma proposta para a devida compreensão dessas práticas de intervenções urbanas enquanto fenômeno e sua função social. Por fim, as análises realizadas permitiram inferir que essa forma de ressignificação do sofrimento gera espaços de resiliência, uma vez que materializam a memória da perda no ambiente urbano, por meios de marco artístico, retratando uma última imagem positiva do falecido, para que outros transeuntes vejam e sejam afetados pelo conhecimento de seus nomes e suas histórias.

Palavras-chave: Memórias Traumáticas. Turismo da Dor. Lugares de Memória. Resiliência.

\begin{abstract}
In the years 1998, 2005 and 2017, three criminal deaths occurred in three spaces close to each other, in the South Zone of the city of Rio de Janeiro. Three middle class youths were brutally murdered and won posthumous tributes, of a sculpture and two graffiti respectively. And in 2018 councilwoman Marielle Franco was murdered, giving rise to a similar social understanding and giving a new meaning to the place where the crime occurred, as well as many others, with artistic interventions. Such spaces and their surroundings, and so many others that punctuate Brazilian cities, could well be called the polygon of violence or the pain circuit, for portraying dead people. In view of this reality, the research presented here deals with an analytical reflection in the light of the concepts of "recollection" and "distraction" by Walter Benjamin, with the communication proposal of Vilém Flusser, also based on the poetics of Fernando Catroga's absence and the cultural studies on the memory of Aleida Assmann, as a proposal for the proper understanding of these practices of urban interventions as a phenomenon and its social function. Finally, the analyzes made it possible to infer that this form of resignification of suffering generates spaces of resilience, since they materialize the memory of the loss in the urban environment, by means of an artistic framework, portraying a last positive image of the deceased, so that other passersby see and be affected by the knowledge of their names and their stories.
\end{abstract}

Keywords: Traumatic Memories. Pain Tourism. Places of Memory. Resilience. 


\section{Introdução}

A cidade do Rio de Janeiro é conhecida mundialmente não apenas por suas diversidades naturais e culturais, pulsante vida noturna e por seu carnaval, mas também pela violência cotidiana que se tornou verdadeira ferida aberta. Nesse sentido, uma prática observada pelas ruas do Rio de Janeiro vem contribuindo para amenizar a dor dos amigos e parentes das vítimas destas mortes trágicas e abruptas, configurando-se como ferramenta de protesto insistente e silencioso. Consistindo em intervenções artístico-urbanas, ora feitas pela comunidade, ora através de ato do poder executivo municipal, essa prática serve ainda como uma derradeira homenagem para evocar a(s) ausência(s) do convívio querido.

Sejam muros grafitados - espalhados por vários locais da cidade -, sejam esculturas, cartazes, frases de efeito, placas, ou outras expressões artísticas, essas manifestações buscam a comunicação em âmbito público, de um luto coletivo e ao mesmo tempo, uma denúncia aberta sobre as circunstâncias da morte. Talvez essa dor materializada no espaço urbano seja como "fio invisível [que] liga objetos [e sujeitos com ou] sem uma relação evidente", ${ }^{1}$ pois a morte (e o morrer) encontra sua representação agregadora nos mais diversos meios, da assim apelidada, "Cidade Maravilhosa".

Apesar de a presente pesquisa focar nos fatos criminosos e sua relação direta com os lugares ressignificados artisticamente pelo viés memorial ou mnemônico, a proposta do método de análise das características gerais - do que se considera aqui com a adjetivação de polígono da violência ou circuito da dor -, pode ser aplicado em outros contextos urbanos e, mesmo, alguns rurais. Trata-se fundamentalmente de lugares que se tornaram como que monumentos (ou documentos) da violência, devido ao encontro co-incidente do espaço do acontecimento criminoso, ou de ruptura social traumática, com a intervenção artística feita em seguida. A observação desses lugares ressignificados deu ensejo a um mapa online e, a partir dele, notou-se a emergência de alguns padrões, dos quais concernem ao que pode ser chamado de prática cultural de fundo tanatológico, que consiste em atuar simbolicamente, por intervenção artístico-urbana, no espaço da ocorrência de algum trauma social e sua posterior ressignificação. ${ }^{2}$ Nisso é possível citar o historiador lusitano Fernando Catroga, quando diz, sobre o ser humano e suas práticas, que

facilmente se encontram representações simbólicas não raro antagónicas entre si. Mas, o seu condicionamento histórico e social não deve fazer esquecer que elas são urdidas por um impulso de raiz metafísica que impele o homem a separar-se da natureza e da animalidade, e a emergir, na escala dos seres,

\footnotetext{
1 NORA, Pierre. Entre Memória e História: a Problemática dos Lugares. Projeto História: Revista do Programa de Estudos Pós-Graduados de História, São Paulo, v. 10, p. 7-28, out. 2012, p. 21.

2 Cf.: Espaços de Recordação - RUPTURAS. Google Maps. (Plataforma Eletrônica). Disponível em: http://tinyurl.com/rupturas. Acesso em: Acesso em: ago. 2019.
} 
como um cultuador de mortos; logo, como um produtor de cultura e de memória. ${ }^{3}$

Serão tratados, neste trabalho, de forma breve, alguns casos que se tornaram emblemáticos em termos de representação imagética nas ruas do Rio de Janeiro: o caso do jovem assassinado em 2005 - Gabriel Marighetti, por tratar-se do que pode ser o primeiro grafite (feito em sua memória), de base cultural tanatológica, passando por Miguel Ayoub, assassinado em 2017 e igualmente retratado na pilastra do viaduto em que caiu alvejado a tiros de fuzil. E o caso mais recente, do assassinato da vereadora Marielle Franco em 2018, cujo local do crime tornou-se inicialmente uma espécie de santuário, recebendo cartazes, frases de efeito e diversos objetos de pessoas afetadas pelo ato de violência e o que ele representou. Essas homenagens espalharam-se também por outras áreas da cidade, país e o mundo, criando diversos memoriais.

Os espaços urbanos que aqui tratados têm uma singularidade, pois foram criados para serem vistos, mas não necessariamente visitados da mesma maneira como quem vai a uma exposição ou museu. E como imputação valorativa, ${ }^{4}$ os signos fúnebres mapeados não seguem a mesma estrutura típica da propaganda (outdoors) e sua característica vitrinista, que objetiva uma divulgação para a venda de algum produto, a não ser que se diga, de modo metafórico, que se quer vender/divulgar que ali no espaço ressignificado, ocorreu uma violência, um trauma social, e que algo deve ser feito como justiça ou reparação da(s) vida(s) perdida(s). Para efeitos de comparação, não se trata de algo como memória-produto, como parte de uma imposição à sociedade pela indústria cultural, mas sim como manifestações setoriais e espontâneas, evoluída como exponencial formulação de exigências revolucionárias na política, traçado em vias publicas e privadas indistintamente. ${ }^{5}$

\section{Uma memória em trânsito}

A cidade do Rio de Janeiro é o conjunto de diferentes cidades, não apenas no ponto de vista administrativo, mas da própria organização social. Aqui falaremos basicamente de dois, o Rio do turista e o Rio do morador. Para este último, com o tempo, os espaços de memória tornam-se invisíveis à dinâmica urbana e aos interesses sociais, pois, tal como apresenta Marcelo Sotratti, "o planejamento urbano como aparelho ideológico [...] pode ser utilizado

\footnotetext{
${ }^{3}$ CATROGA, Fernando. O culto dos mortos como uma poética da ausência. ArtCultura, Uberlândia, v. 12, n. 20, p. 163-182, jan.-jun. 2010.

${ }^{4}$ Isto é, um objeto qualquer que receba uma atribuição que o valore, dotando-o de memória-referente, de modo sígnico-cultural. Cf.: FLUSSER, Vilém. Comunicologia: reflexões sobre o futuro: as conferências de Bochum. São Paulo: Martins Fontes, 2014.

${ }^{5}$ Portanto, não aos moldes do que fala Theodor Adorno e sim se aproximando da perspectiva de Walter Benjamin. Cf.: ADORNO, Theodor W. Industria cultural e sociedade. São Paulo: Paz e Terra, 2002; BENJAMIN, Walter. A obra de arte na era de sua reprodutibilidade técnica. In: Obras escolhidas I. São Paulo: Brasiliense, 1987.
} 
como um dos aparelhos coercitivos do Estado através da organização e ordem espacial". ${ }^{6}$ Mas a arte tem o poder de driblar as convenções e acessar os mais distintos lugares, se fazendo presente mesmo sem a consciência dos olhares acostumados com a paisagem. Nesse exato ponto, trazem-se para a discussão dois conceitos encontrados no texto "A Obra de Arte na Era da Reprodutibilidade Técnica", de Walter Benjamin, a saber, os conceitos de "distração" e "recolhimento":

A distração e o recolhimento representam um contraste que pode ser assim formulado: quem se recolhe diante de uma obra de arte mergulha dentro dela e nela se dissolve, como ocorreu com um pintor chinês, segundo a lenda, ao terminar seu quadro. A massa distraída, pelo contrário, faz a obra de arte mergulhar em si, envolve-a com o ritmo de suas vagas, absorve-a em seu fluxo. ${ }^{7}$

Ainda que as intervenções sejam um retrato da pessoa falecida, como memória que se quer perpetuar, por encontrarem-se à mostra dos transeuntes, não seria ético pensá-las como arte feita para a "distração" dos passantes, sendo nesse intuito, um convite ao recolhimento para que se saiba que um crime ocorreu e, de algum modo, a sociedade seja instada a participar, ao menos na solidariedade de um luto que não se quer restrito ao interior familiar. Como prática cultural tanatológica, essa estrutura do circuito comunicacional - que consiste resumidamente na valoração pela sequência causal dos eventos pessoais, aqui em particular marcado pelo trauma social e ressignificação pela arte - trás um signo fúnebre que passa a ser replicado quase como um ato reflexo, como pode ser entrevisto a partir da compreensão das imagens adiante:

\footnotetext{
${ }^{6}$ SOTRATTI, Marcelo Antonio. A ideologia espacial na patrimonialização e gestão de bens culturais em áreas gentrificadas. Boletim Campineiro de Geografia, Campinas (SP), v. 6, p. 303-323, 2016, p. 306.

7 BENJAMIN, Walter. A obra de arte na era de sua reprodutibilidade técnica. In: Obras escolhidas I. São Paulo: Brasiliense, 1987.
} 
Figura 1 - Um transeunte ante um grafite de Marielle Franco, vereadora carioca assassinada.

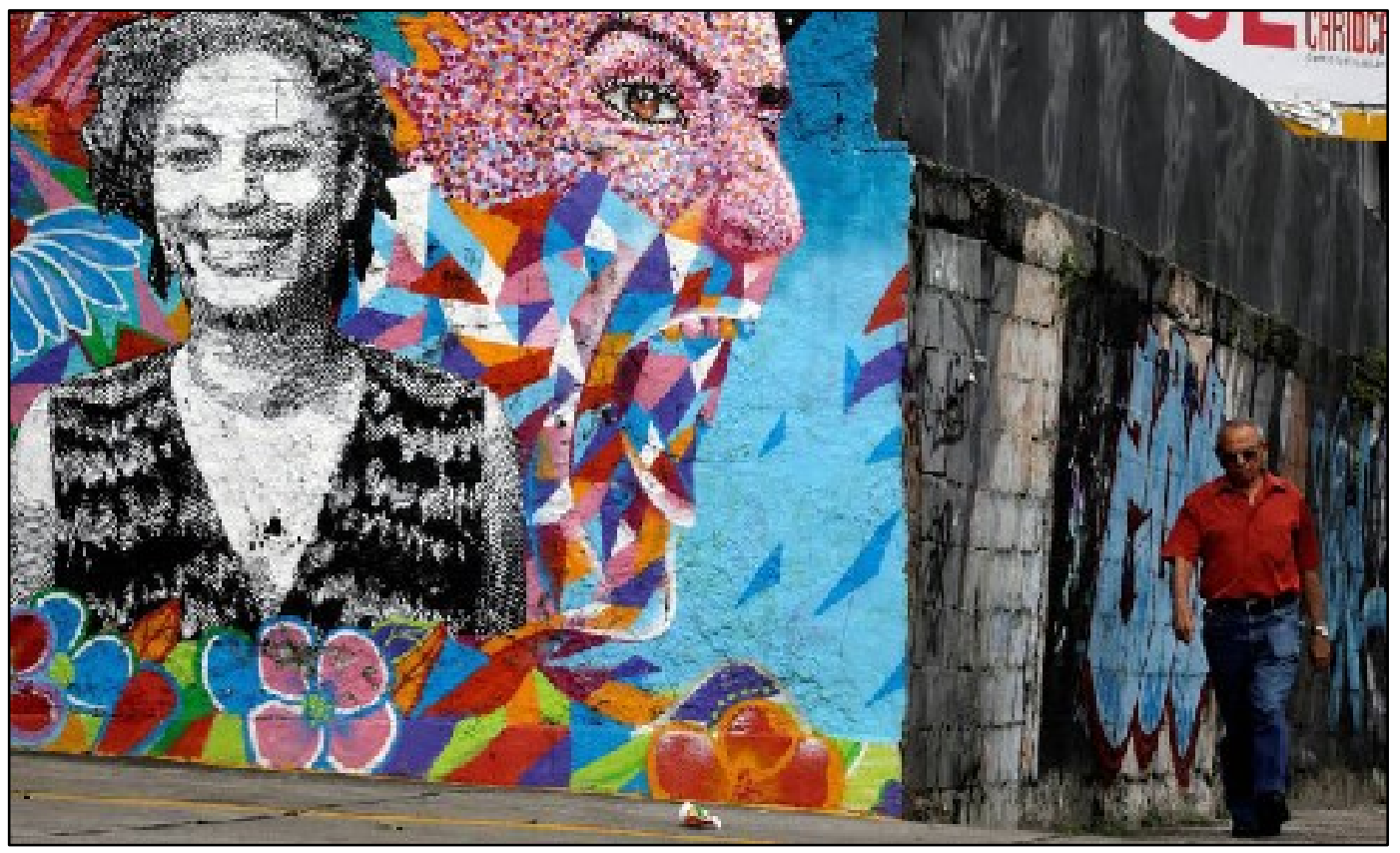

Fonte: MORAES, Sérgio. A duas semanas de deixar PGR, Raquel Dodge estuda federalização do caso Marielle. El País. (Site). Publicado em: 12 mar. 2019. Disponível em:

https://brasil.elpais.com/brasil/2019/09/04/politica/1567563791_734607.html. Acesso em: 10 jan. 2020.

Figura 2 - Mural com Marielle no Rio de Janeiro.

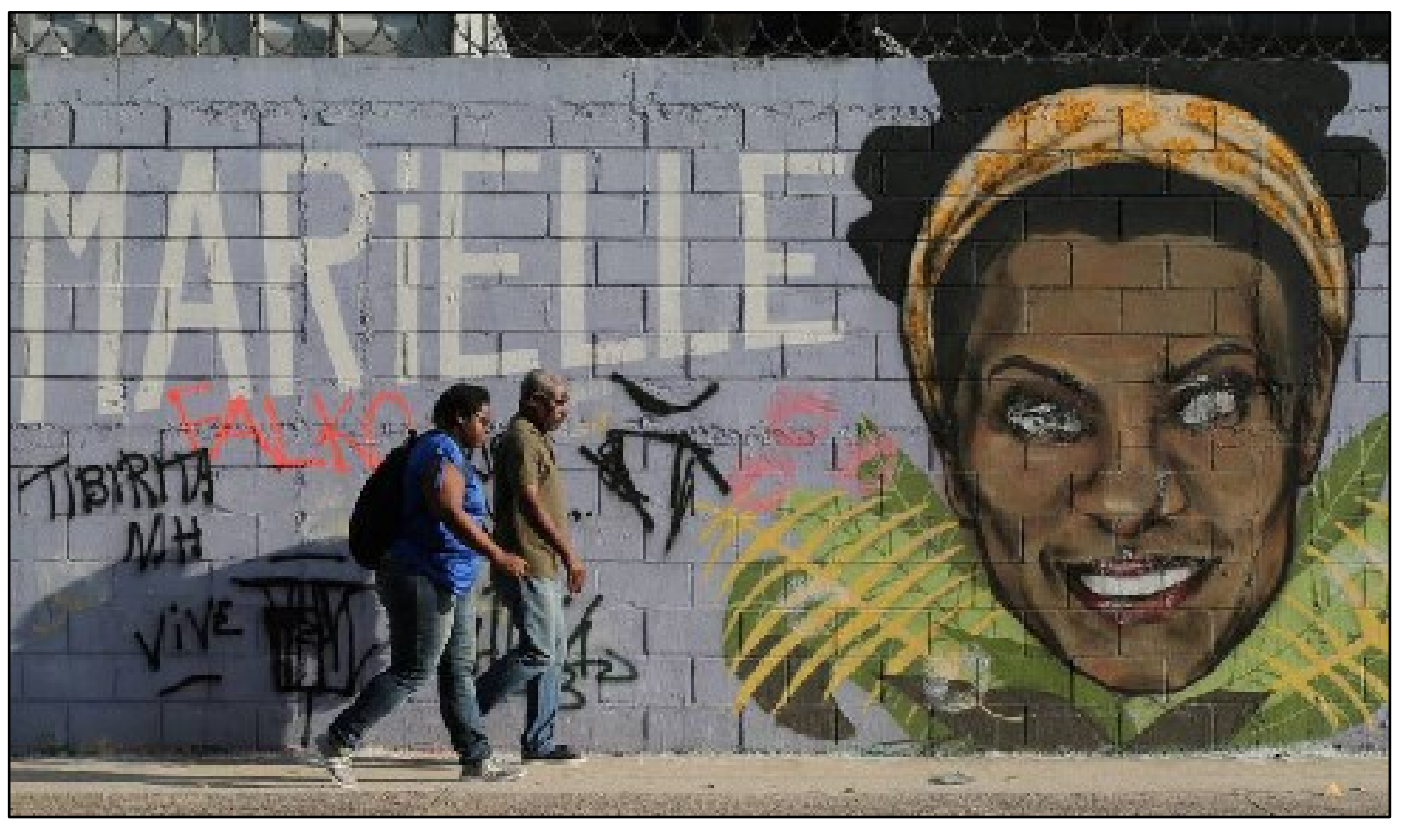

Fonte: MORAES, Sérgio. "Quem mandou matar Marielle?": o clamor que despertou pelo Brasil. El País. (Site). Publicado em: 16 mar. 2019. Disponível em:

https://brasil.elpais.com/brasil/2019/03/16/politica/1552740136_102710.html. Acesso em: 10 jan. 2020. 
Essa é uma camada de entendimento pouco analisada no âmbito da política cultural: o das formas espontâneas de preservação das memórias ruins ou relacionadas à violência no cotidiano das ruas, frutos de evento abrupto, como latrocínios e homicídios. Certamente que, na escala de valores que permeiam os critérios patrimoniais, a criminalidade não figura entre elas. Aí reside uma das problemáticas que se quer debater. Entretanto cabe esclarecer que não se trata de defender o crime como valor cultural, mas sim que a partir dele há uma ressignificação cultural, empreendendo inclusive uma certa estética e narrativa, que busca dar sentido às experiências de dor das pessoas no contexto da violência urbana. Essa ressignificação cultural pode ser observada tanto na presença de símbolos, relacionados a eventos trágicos ou mesmo no seu deslocamento, haja visto o caso do túnel CatumbiLaranjeiras, renomeado, após um desmoronamento durante suas obras, para Túnel Santa Barbara.

Por conta do processo de expansão urbana da cidade do Rio de Janeiro, foi necessário abrir vários caminhos que melhorassem o fluxo viário em direção ao centro, construindo-se vários túneis. Sobre essa especificidade podemos dizer que:

a mistura dos elementos que ao atingirem o "ponto de ebulição" e com a sucessiva expansão e ocupação humana da cidade, no bojo do processo histórico, vão engendrar a necessidade da construção de túneis, ligando os diversos pontos da cidade, além de propiciar, com os mesmos, a incorporação de áreas periféricas, anteriormente isoladas. ${ }^{8}$

Nesse processo de ampliação da cidade o túnel Catumbi-Laranjeiras teve seu nome trocado para Túnel Santa Bárbara, pois de acordo com Carvalho: "A alcunha oficial, Santa Bárbara, decorre da tradição cristã, advinda das Minas Gerais do tempo da colônia, na qual a santa era cultuada como a protetora dos mineiros e dos trabalhadores em galerias subterrâneas". ${ }^{9}$ Isso porque, durante sua construção houve um desabamento e morreram cerca de 20 operários (o número real é incerto). Como homenagem, o governador Carlos Lacerda à época da inauguração do túnel em 22 de abril de 1964, mandou construir uma capela aos mortos justamente no 'vão' que restou após o ruir das rochas, colocando aí a imagem em madeira de Santa Bárbara mais um painel azulejar encomendado à artista plástica Djanira da Motta e Silva. Além disso, "seus nomes foram inscritos em lápide, contendo, textualmente, os dizeres: Tu, que passas por este caminho / que a nossa morte abriu no seio da pedra / pede a Santa Bárbara que tenhamos a vida / no seio de Deus". ${ }^{10}$

O acesso a essa capela/gruta era muito difícil, afora a poluição que a castigou por muitos anos e ao painel em seu interior. Por conta disso ele foi removido graças a uma decisão de Darcy Ribeiro, então presidente da Fundação Anita Mantuano de Artes do Estado do Rio de Janeiro (FUNARJ), em 1985. No ano de 1996 o painel foi restaurado e instalado em um pátio

\footnotetext{
8 CARVALHO, Ronaldo Cerqueira. Rio de Janeiro - uma cidade conectada por túneis. Instituto Pereira Passos - Armazém de DADOS, Rio de Janeiro, v. 4, p. 1-57, 2004, p. 9.

${ }^{9}$ Ibidem, p. 26.

${ }^{10}$ Idem.
} 
chamado Lily Marinho, no Museu Nacional de Belas Artes, onde pode ser apreciado até os dias de hoje.

Figura 3 - Djanira da Mota e Silva. Azulejos, antes no Túnel Santa Bárbara, Rio de Janeiro, 1964.

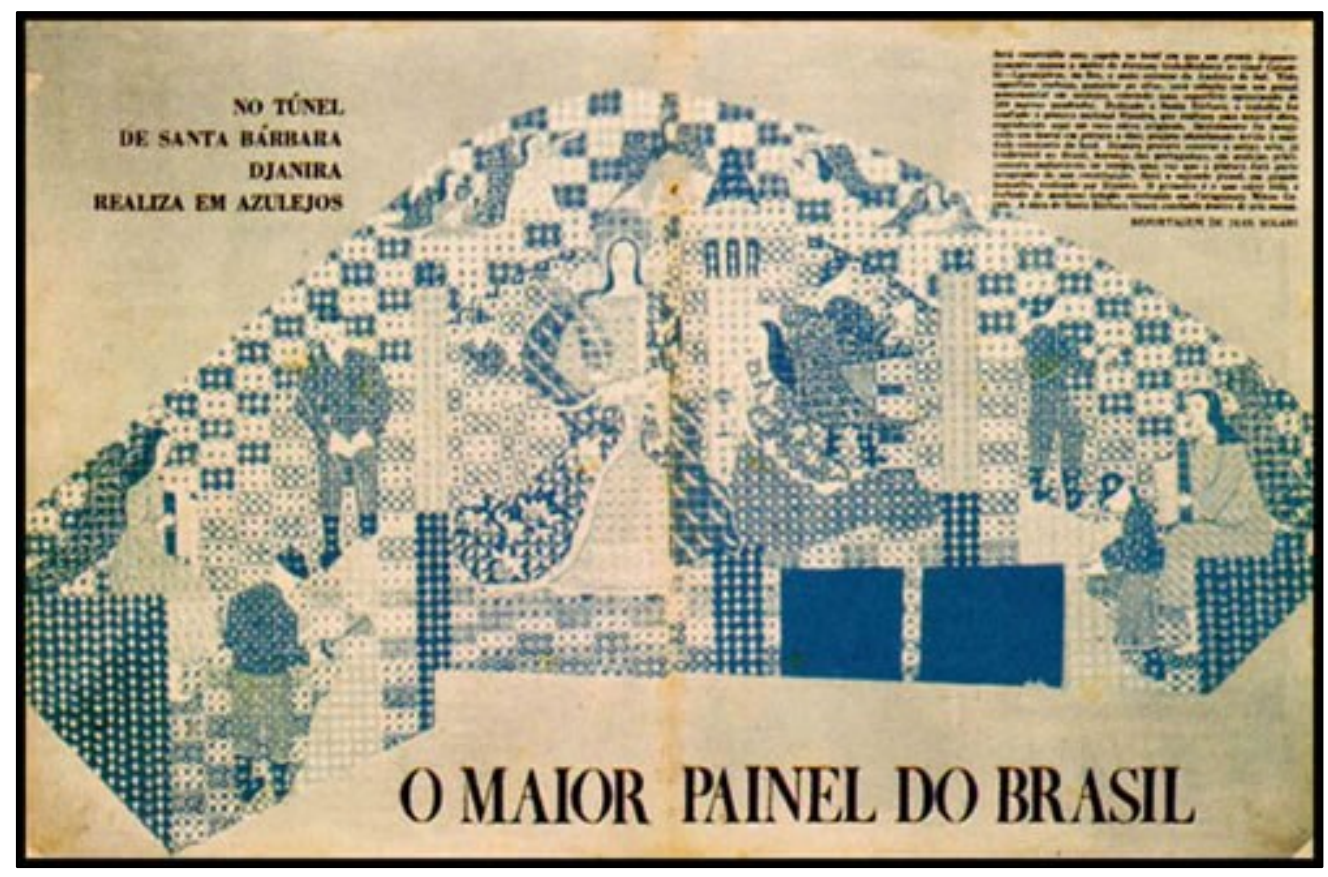

Fonte: SILVA, Raul Mendes. Djanira. (Verbete). Dicionário de Artistas do Brasil. (Recurso Eletrônico). Disponível em: http://www.raulmendessilva.com.br/brasilarte/nacional/primeira.html. Acesso em: 10 jan. 2020.

Caberiam as mais diversas considerações diante da história pouco conhecida do Túnel Santa Barbara, mas ressaltam-se duas das mais pertinentes ao presente artigo: perdeu o túnel o que lhe dava nome e sua maior significância histórica; e perderam os operários mortos a referência mnemônica por meio da qual, de algum modo, permaneciam imortalizados.

Havia um certo dever de memória, mesmo em seu uso político como resposta à cidade e seus habitantes ante a tragédia. Esse dever, com o tempo, diluiu-se rumo ao esquecimento do entorno ou para o exclusivo conhecimento de historiadores, memorialistas e curiosos. Pois "como sustenta Pierre Nora, os 'lieux de mémoire' sugerem a paragem do tempo e, de certa maneira, a imortalização da morte". ${ }^{11}$

A "paragem do tempo" movimentou-se e, mesmo em jornais de época, os nomes dos operários mortos não são mais encontrados. Outras iguais tragédias assolaram a cidade ao longo dos anos, como recentemente a queda da ciclovia Tim Maia, a queda do Edifício Palace II e dos Edifícios Liberdade e Colombo. Se voltarmos algumas décadas no tempo é possível citar ainda o desabamento da Oficina de Trem de São Diogo e da Pedreira São Diogo. Deixamos de propósito sem a data ou demais referências, como uma espécie de metáfora do esquecimento, cabendo ao leitor que persiga as lembranças que porventura the despertem a curiosidade.

${ }^{11}$ CATROGA, Fernando. O culto dos mortos... Op. cit., p. 171. 


\section{Memória urbana seletiva e o turismo}

Falar de questões como polígono da violência ou circuito da dor, em uma cidade como o Rio de Janeiro, é perpassar obrigatoriamente em tratar o Rio dos turistas, dos quais são comumente conhecidos por frequentarem espaços tidos por excepcionais, espectadores que são por certa ideação de beleza ou fruição estética: espaços vendáveis. Mas há esses outros espaços, de inconvenientes registros discursivos de uma dor que se origina a partir da violência, destacando-se pelos grafismos e/ou monumentos que os tornam visíveis para o público. E do momento que se encontram à vista de todos os passantes, os guias e demais profissionais do turismo podem pensá-los em roteiro próprio, com a ressalva constante de que são memórias, reais e sôfregas. Há uma ênfase ética para isso, o do desrespeito ao luto imputado na figura retratada, na inserção da dor naquele entorno urbano.

Como exemplo emblemático de desrespeito a memórias alheias, o caso exposto pelo escritor israelita de origem alemã, Shahak Shapira, que registrou os abusos de alguns turistas no Monumento aos Mortos de Auschwitz, como podemos observar nas imagens abaixo:

Figura 4 - Yoga is a connection with everything around us.

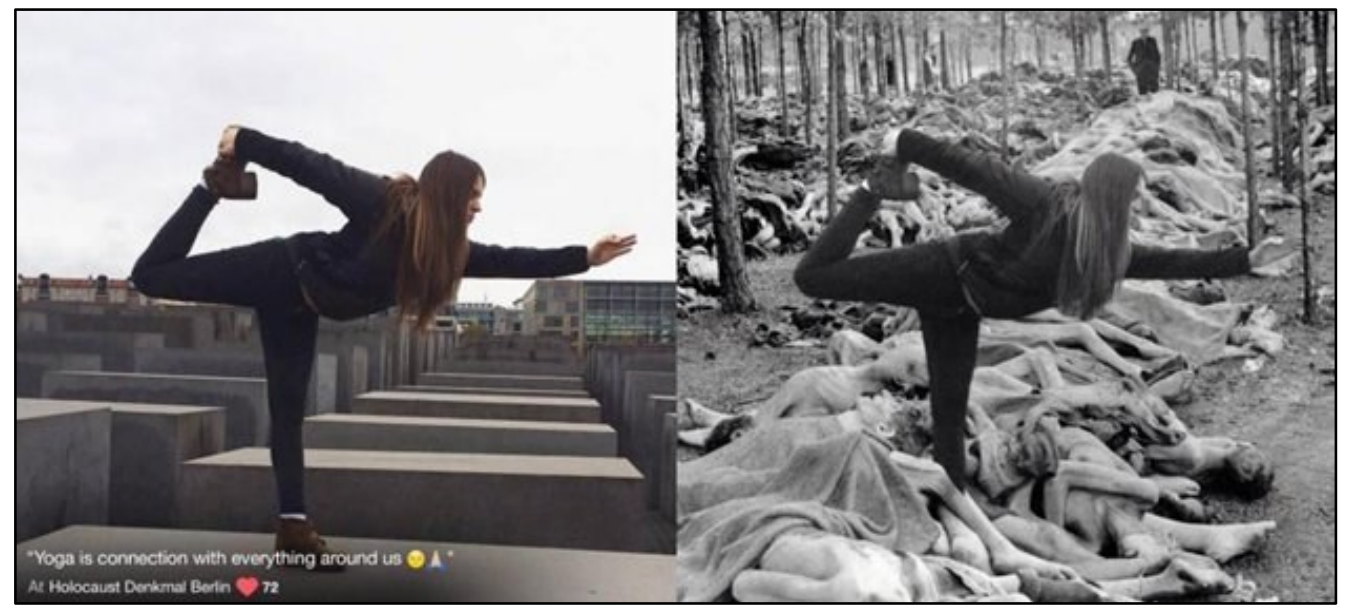

Fonte: PAIVA, Vitor. Artista expõe o desrespeito de selfies tiradas por turistas no Memorial do Holocausto. Hypeness. (Site). Publicado em: jan. 2017. Disponível em:

https://www.hypeness.com.br/2017/01/artista-expoe-o-comportamento-contraditorio-de-turistas-nomemorial-do-holocausto/. Acesso em: 10 jan. 2020.

Em exemplo mais próximo, as muitas imagens de Marielle Franco espalhadas não apenas pelo Rio de Janeiro, mas também pelo país e pelo mundo, eventualmente chamam atenção - convidam ao "recolhimento" -, como memorial da violência ou espaço de resiliência. ${ }^{12}$ Porém é necessário mencionar que, mesmo havendo respeito e admiração por determinado grupo, tais homenagens à vereadora assassinada causam indignação a outros

${ }^{12}$ Cf.: Marielle - Homenagens. Composição de Hércules da S. X. Ferreira. Google Maps. (Plataforma Eletrônica). Disponível em: https://tinyurl.com/memoriamarielle. Acesso em: ago. 2019. 
grupos que, a seu próprio modo, ofendem e agridem com violento gesto simbólico a memória que se preserva.

Figura 5 - Malala e Marielle Franco.

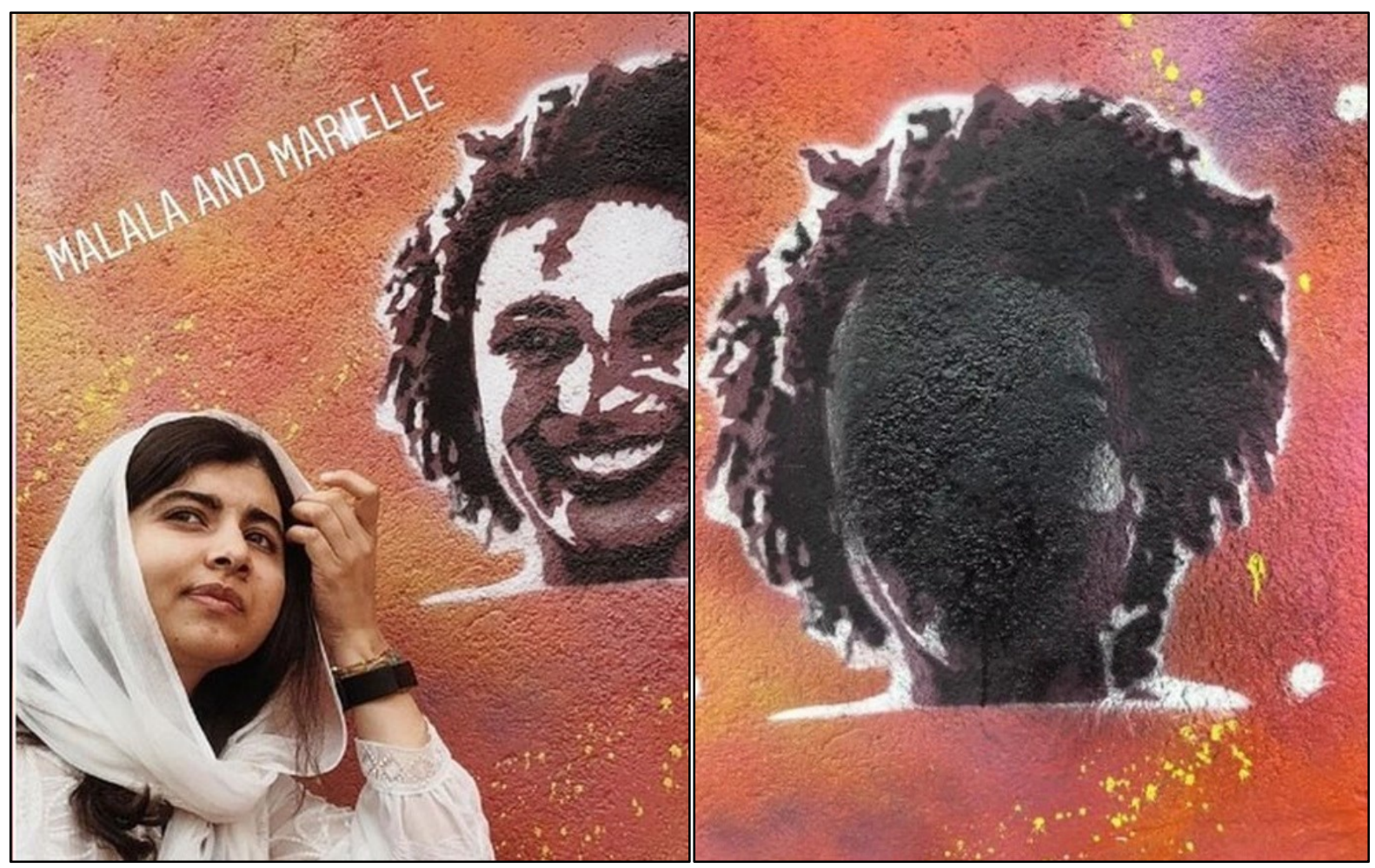

Fonte: ALVES, Raoni. Grafite em homenagem a Marielle feito por Malala Yousafzai é vandalizado no Rio G1. (Site). Publicado em: $18 \mathrm{dez}$. 2018. Disponível em: https://g1.globo.com/rj/rio-dejaneiro/noticia/2018/12/18/grafite-em-homenagem-a-marielle-feito-por-malala-yousafzai-e-vandalizadono-rio.ghtml. Acesso em: 10 jan. 2020.

A discussão decorrente vai ao encontro de certa ética dos afetos, ou de suas normas/convenções sociais, que no momento escapa do objetivo do presente artigo, cabendo também apontamentos críticos em que, se não for o caso de uma moral preexistente impondo limites, pode-se pensar certo viés punitivo para tais comportamentos se estes forem considerados não apenas inadequados - inoportunos -, mas agressivos de alguma maneira à honra da pessoa falecida. ${ }^{13}$

\footnotetext{
${ }^{13}$ Conforme o caso da placa removida e destruída e posteriormente emoldurada em gabinete próprio. CAPELLI, Paulo. Deputado que quebrou placa com nome de Marielle emoldurou fragmento e botou na parede. Extra. (Site). Publicado em: 14 fev. 19. Disponível em: https://extra.globo.com/noticias/rio/deputado-que-quebrou-placa-com-nome-de-marielle-emolduroufragmento-botou-na-parede-23453055.html. Acesso em: ago. 2019.
} 


\section{Do efêmero ao acontecimento}

A dor exposta nos espaços públicos na representação de grafites, esculturas, marcos ou quaisquer outras formas de expressão, contribui (como já escrito), não apenas para o processo de enlutamento dos entes queridos do morto, mas também como espécie de aviso ou alerta para aquele lugar que, associado a uma ruptura violenta e criminosa, adquire uma espécie de marca. Um tipo de apelo materializado, por tratar-se de assassinatos e latrocínios, que permite outras formas de interpretação quando diante delas e/ou pesquisando por suas histórias e memórias.

Dando maior base ao argumento apresentado, cita-se que,

Todo o jogo do simbolismo funerário parece apostado em edificar memórias e em dar uma dimensão veritativa ao ausente. Porém, aquilo que se pretende recordar emerge do imenso e escondido continente do recalcado. Isto é, se toda a memorização, enquanto construto mediado pelo presente $[\ldots]$, tem a sua outra face no consciente ou inconscientemente esquecido, também o cemitério, como lugar de memória, tem implícito um invisível fundo de amnésia. ${ }^{14}$

Cabe lembrar que, na história da formação das sociedades, a relação com a morte teve espaço primordial, sendo apontado por vez como uma das justificativa para a formação de grupos sedentários, visto que alguns grupos não queriam abandonar seus mortos. ${ }^{15}$ Sem falar na constante relação de proximidade entre os acampamentos e seus contextos funerário.

Por mais que estas artes não se encontrem no cemitério, o discurso delas diz respeito a esse campo santificado, possivelmente influenciando em seu entorno na subjetividade dos transeuntes.

Trazendo outros exemplos, encontra-se à saída do Túnel Santa Bárbara, abaixo do viaduto Engenheiro Noronha e em sua área contígua, uma região que bem poderia ser adjetivada com os sugestivos epítetos de 'polígono da violência' por haver a possibilidade de traçar um verdadeiro 'circuito da dor', ou mesmo 'vitrines da perda' e demais termos similares.

Afinal, guarde-se os nomes e as datas de falecimento: Ana Carolina da Costa Lino (04/1998), Gabriel Marighetti (11/2005) e Miguel Ayoub (04/2017). Essa ordem será seguida, pois uma terrível proximidade os iguala em incômoda recordação, pois suas mortes se deram de modo traumático, em consequência da violência dos projéteis disparados por armas de fogo. Por conta disso, e em ordem respectiva, ergueu-se como homenagens póstumas, uma escultura e dois grafites. A distância temporal entre elas é relativamente curta: 1998, 2005 e 2017. Mas o passante que deter-se nelas, "recolhido", não encontrará maiores explicações, senão a marca implícita de uma ausência, ampliada por palavras-chave que, embora direcionem o entendimento, deixam apenas subentendida a questão da Morte.

\footnotetext{
${ }^{14}$ CATROGA, Fernando. O culto dos mortos... Op. cit., p. 168.

15 BINFORD, S. R. A structural comparison of disposal of the dead in the Mousterian and the Upper Paleolithic. Southwestern Journal of Anthropology, v. 24, n. 2, 139-154, Summer 1968.
} 
É possível pesquisar as diversas referências tanatológico-urbanas em endereços de buscadores, bastando partir dos nomes ou demais referências descritivas desse tipo de manifestação, mas aqui nos pautaremos apenas nestes três casos.

Iniciando, dentro de uma sequência cronológica, encontram-se as manifestações referentes à morte de Ana Carolina, cuja escultura próxima à Maternidade Escola da Universidade Federal do Rio de Janeiro (UFRJ) é ilustrada com uma placa de bronze contendo os devidos nomes envolvidos. Inclusive, para reforçar o certo entendimento de referência histórica ou mesmo turístico/informativo. Essa escultura será o ponto de partida para uma marcha por este circuito de memórias sensíveis descritas aqui.

Pesquisando sobre o caso, encontra-se a notícia da Folha de São Paulo, escrita em 1998, que aparece da seguinte maneira: "Ana Carolina da Costa Lino, 18, morreu ontem de manhã no Hospital Souza Aguiar (centro do Rio), sete horas após ser atingida por cinco tiros de FAL (fuzil automático leve), arma de uso restrito a militares" ${ }^{16} \mathrm{E}$ fica-se sabendo que ela estava

acompanhada pela prima Ana Paula Lobato, 18, colega de sala no curso prévestibular do Centro Educacional da Lagoa, em Humaitá (zona sul). Ana Paula contou na 9a DP, no Catete (zona sul), que o Palio começou a perseguir o Renault dentro do túnel. As estudantes tinham deixado a escola minutos antes. Na saída do Santa Bárbara, o Palio atravessou na frente do Renault. ${ }^{17}$

Ana Carolina veio a óbito sete horas após sofrer o crime. Mas sua escultura só pode ser realizada por força de lei, cuja autoria pertence a vereadora Leila do Flamengo. O processo tramitou por exatos 1147 dias, sendo a lei publicada no Diário Oficial do Município no dia 19 de junho de 2001, com a seguinte redação transcrita abaixo na íntegra,

O PREFEITO DA CIDADE DO RIO DE JANEIRO,

faço saber que a Câmara Municipal decreta e eu sanciono a seguinte Lei:

Art. $1^{\circ}$ Fica denominada Espaço Pela Paz-Ana Carolina da Costa Lino, a área embaixo do viaduto formado pela pista de acesso ao Túnel Santa Bárbara, na Rua das Laranjeiras.

Art. $2^{\circ}$ Fica o Poder Executivo autorizado a erigir um monumento no local especificado.

Art. $3^{\circ}$ Esta Lei entra em vigor na data de sua publicação.

CESAR MAIA. ${ }^{18}$

Para nosso artigo não localizamos as dimensões da referida escultura. Mas é possível dizer que corresponde à altura de uma jovem de 18 anos, que foi feita a partir de sua imagem/corpo, com expressão alegre no rosto e à sua destra uma pomba, em espaço próximo à Maternidade Escola da UFRJ. Frise-se que o lugar onde ela foi erguida passou a ser denominado Espaço Pela Paz - Ana Carolina da Costa Lino.

\footnotetext{
16 TORRES, Sérgio. Estudante é morta a tiros de fuzil no Rio. Folha de São Paulo. (Site). Publicado em: 16 abr. 1998. Disponível em: https://www1.folha.uol.com.br/fsp/cotidian/ff16049827.htm. Acesso em: 10 jan. 2020.

17 Idem.

${ }^{18}$ RIO DE JANEIRO. Lei Municipal n. ${ }^{\circ}$ 3.239, de 12 de junho de 2001. Dá o nome de Espaço Pela Paz Ana Carolina da Costa Lino, à área embaixo do viaduto formado pela pista de acesso ao Túnel Santa Bárbara, na Rua das Laranjeiras e dá outras providências. Rio de Janeiro, 2001.
} 
Figura 6 - Escultura de Ana Carolina da Costa Lino, 2001.

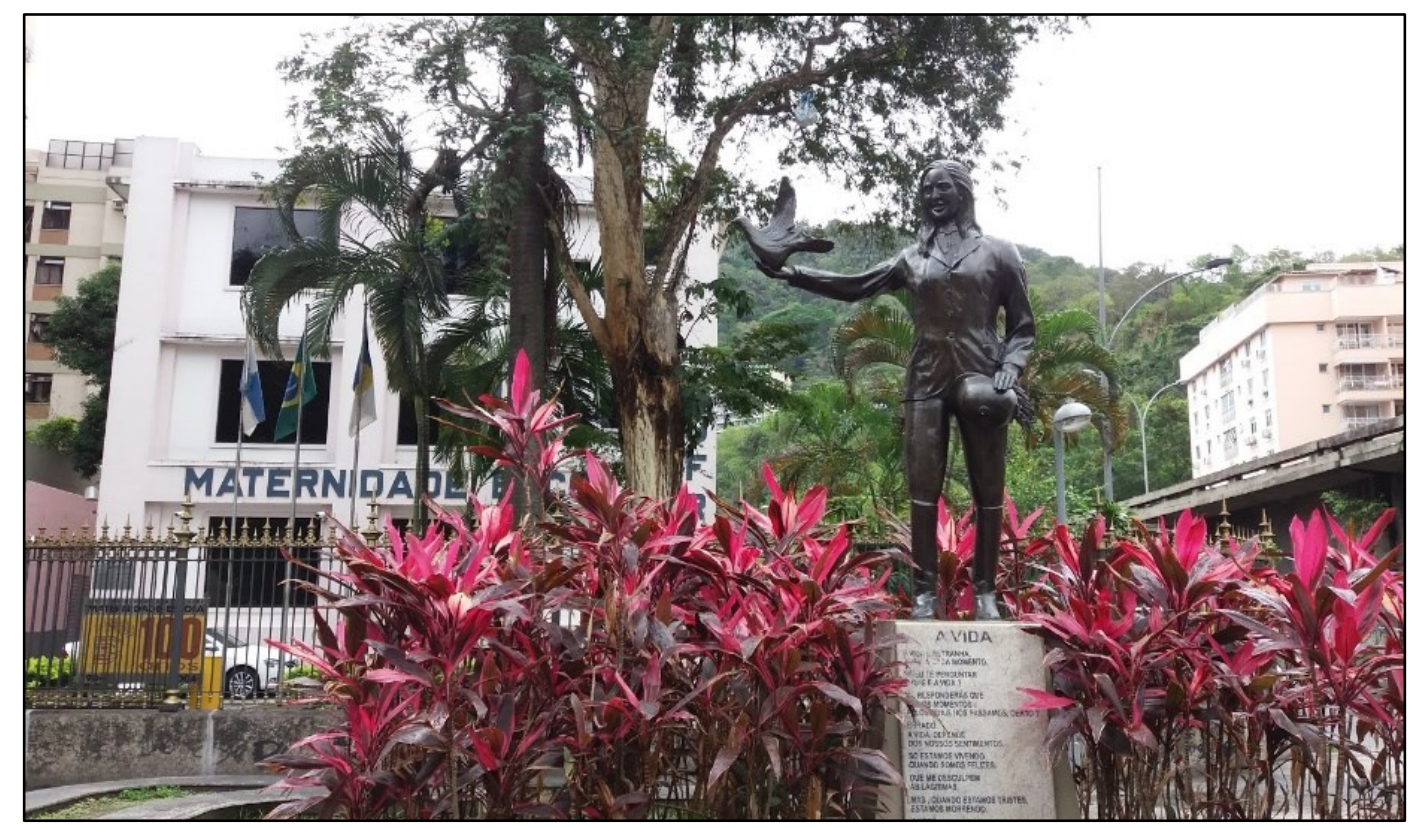

Fonte: Acervo Pessoal, 2001.

$\mathrm{Na}$ inconveniente coincidência dos fatos, há no muro oposto, do outro lado da calçada onde se encontra a referida escultura, um grafite com o rosto sorridente de outro jovem, pintado em 2005 por Carlos Esquivel Gomes da Silva, mais conhecido pela sua assinatura artística 'Acme', retratando o assassinato de Gabriel Marighetti.

Em seu artigo, Ferreira cita que a coluna Gente Boa ( $O$ Globo) noticiou com o título "O grafite é a solução", que

um grupo de jovens classe-média da Zona Sul carioca ter convidado o grafiteiro Acme 23, [...], para realizar um desenho em um muro do rosto de Gabriel Marighetti dos Santos, de 19 anos, assassinado por um menor que dias antes havia roubado o discman e o tênis de seu irmão. A matéria também é composta por foto e pelo depoimento de Acme que diz "Eles me surpreenderam por ser molecada de classe média. Eu moro na favela, já vi muito irmão morrer e até hoje não desenhei nenhum na parede". ${ }^{19}$

\footnotetext{
${ }^{19}$ FERREIRA, Soraya Venegas; ARCO, Débora Galeano. De pichação à manifestação artística: Um estudo dos graffitis de ACME 23 no âmbito da folkcomunicação. Revista Internacional de Folkcomunicação, v. 12, p. 55-73, 2014, p. 74.
} 
Figura 7 - Grafite de Gabriel Marighetti, 2005.

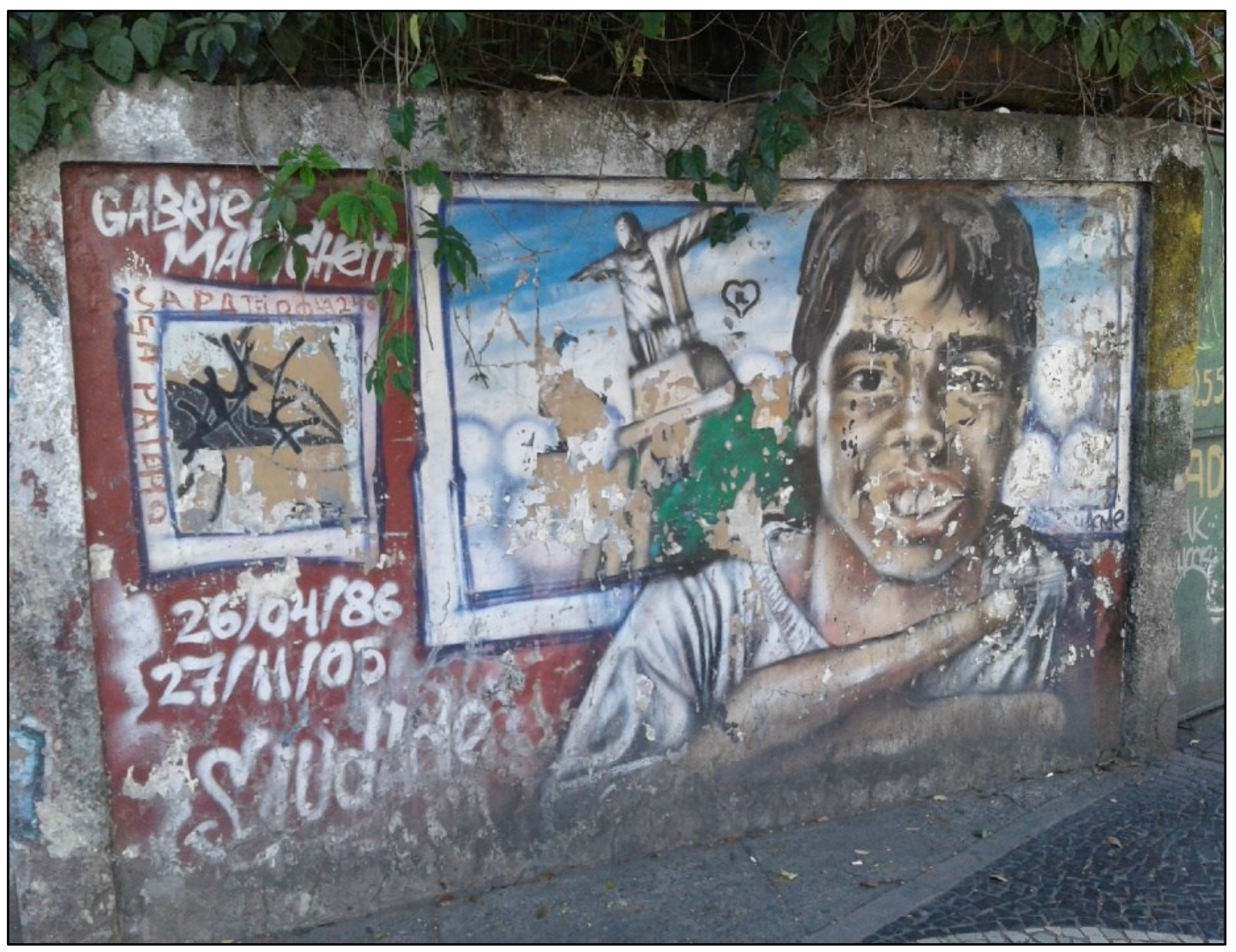

Fonte: Acervo Pessoal, 2005.

A fala do grafiteiro Acme associa-se uma análise do professor Marcelo Sotratti, sobre a ideologia presente na espacialidade urbana:

A partir de uma análise crítica do conceito de ideologia de Althusser, Berdoulay (1985) ressalta que a ideologia pode ser representada por um sistema de representações - mitos, ideias ou imagens - formados num contexto histórico que responde aos anseios de determinada classe dominante. A relação de dominação ideológica se dá através de uma falsa consciência, de forma a permitir a reprodução dos interesses dessa classe dominante. ${ }^{20}$

Encerrando essa marcha, pelo "circuito da dor", o grafite encomendado em homenagem a Miguel Ayoub Zakhour (Figura 8) por amigos ao mesmo Acme, encontra suporte em uma das pilastras do viaduto. Está pintado de meio corpo, com sorriso no rosto, trajando uma camisa verde, e no horizonte ao fundo há a silhueta de uma moto com uma figura segurando um capacete. A notícia esclarece:

Filho único, o rapaz foi morto a poucos metros do portão de casa. Miguel tinha saído com a namorada para dar uma volta de moto quando os dois foram

\footnotetext{
${ }^{20}$ SOTRATTI, Marcelo Antonio. A ideologia espacial na... Op. cit., p. 307.
} 
abordados por bandidos no Viaduto Engenheiro Noronha, por volta de Oh30m da sexta-feira. ${ }^{21}$

De todos os jovens, o crime que aconteceu a Miguel Ayoub foi o mais noticiado por diversos veículos de imprensa, dentre os casos abordados aqui.

Figura 8 - Grafite de Miguel Ayoub, 2017.

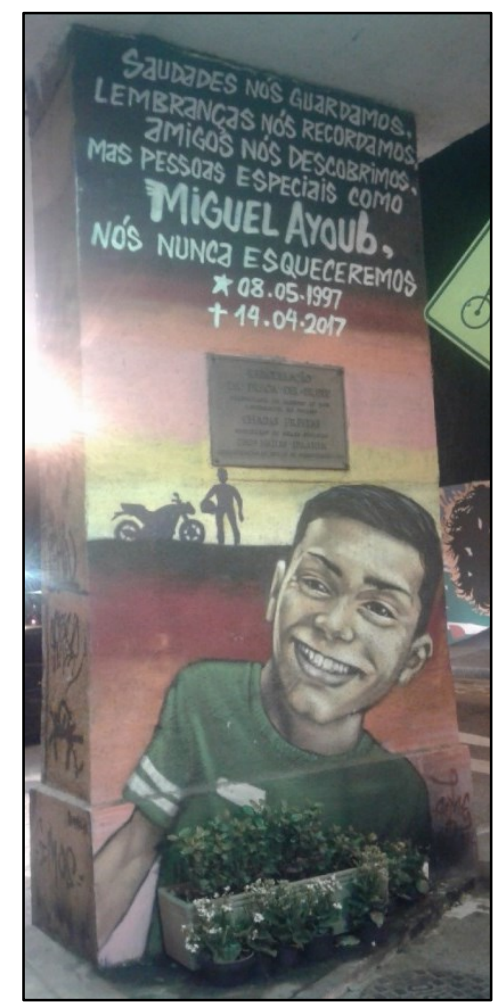

Fonte: Acervo Pessoal, 2017

Atente-se que, por princípio condutor dos casos aqui apresentados, importa a relação direta do local onde os crimes ocorreram, com a permanência das manifestações materiais e artísticas referentes a cada um deles. De acordo com Marcelo Sotratti, ao tratar da ideologia presente na espacialidade urbana trazida por Berdoulay, existem três eixos de construção ideológica do espaço: "os conflitos sociais gerados por imposições ideológicas, o poder simbólico da cultura e da paisagem e a aproximação entre totalidade e finalidade no espaço". ${ }^{22}$.Importante ressaltar que no presente artigo os termos "espaço", "lugar", "localidade" e demais correlatos, são utilizados sem a rigidez técnica e acadêmica característico da geografia, para retratar a fluidez conferida pela arte, pois, de acordo com BARROS "a obra de arte não [é vista] como invasora de onde é colocada, mas sim de onde elas se encontram, estabelecendo um diálogo com o local". ${ }^{23}$

\footnotetext{
${ }^{21}$ ZUAZO, P. "Queria ter um neto", diz pai no enterro de jovem assassinado em Laranjeiras. Extra. (Site). Publicado em: 16 abr. 2017. Disponível em: https://extra.globo.com/casos-de-policia/queria-ter-umneto-diz-pai-no-enterro-de-jovem-assassinado-em-laranjeiras-21215265.html. Acesso em: 10 abr. 2018. 22 SOTRATTI, Marcelo Antonio. A ideologia espacial na... Op. cit., p. 307.

${ }^{23}$ BARROS, Anna. Espaço, lugar e local. Revista USP, São Paulo, n. 40, p. 32-45, fev. 1999, p. 34.
} 
Portanto, faz-se aqui uma aproximação com os conceitos utilizados pela política de patrimônio cultural do Instituto do Patrimônio Histórico e Artístico Nacional (IPHAN), visto que os casos apresentados são manifestações culturais relacionadas à memória sensível e cuja permanência poderia se beneficiar dos instrumentos de acautelamento. Nesse sentido há uma categoria de bens culturais chamada "lugares", cabendo destacar a definição encontrada no Inventário Nacional de Referências Culturais - INRC:

5. Lugares. Toda atividade humana produz sentidos de lugar. Neste inventário serão incluídos especificamente aqueles que possuem sentido cultural diferenciado para a população local. São espaços apropriados por práticas e atividades de naturezas variadas (exemplo: trabalho, comércio, lazer, religião, política, etc.), tanto cotidianas quanto excepcionais, tanto vernáculas quanto oficiais. Essa densidade diferenciada quanto a atividades e sentidos abrigados por esses lugares constitui a sua centralidade ou excepcionalidade para a cultura local, atributos que são reconhecidos e tematizados em representações simbólicas e narrativas. Do ponto de vista físico, arquitetônico e urbanístico, esses lugares podem ser identificados e delimitados pelos marcos e trajetos desenvolvidos pela população nas atividades que Ihes são próprias. Eles podem ser conceituados como lugares focais da vida social de uma localidade. ${ }^{24}$

O sentido amplo apresentado no INRC, ferramenta de identificação e mapeamento de bens culturais, não se reflete no instrumento de reconhecimento dos patrimônios culturais de natureza imaterial, o Registro. No texto do Decreto n. ${ }^{0}$ 3.551/2000, o Livro de Registro dos Lugares (art. 10, inciso IV) é destinado à inscrição de "mercados, feiras, santuários, praças e demais espaços onde se concentram e reproduzem práticas culturais coletivas", indicando a expectativa de inclusão entre o seleto grupo de bens culturais que figuram como Patrimônios Culturais do Brasil, os lugares de memórias que comumente associamos a "boas memórias", ou referências culturalmente auspiciosas. A ideia de reconhecer lugares lembrados pela dor não parece ter sido, ainda, testada pela política federal de patrimônio cultural, o que não impede que sejam abordados no amplo sentido que um lugar possa ter enquanto referência cultural, de marcos espaciais (re)significados cotidianamente pela comunidade que o vivência. Ou, mesmo dentro do âmbito de patrimônio sensível, conceito ainda incipiente enquanto instrumentos administrativos, mas que reconhece o valor de resiliência dos locais relacionados à memória sensível. ${ }^{25}$

Destacam-se ainda os dizeres do arquiteto e urbanista Washington Fajardo para quem "o grafite é uma forma de arte que assume um papel de contestação da realidade. Quando ele se torna uma voz da sociedade clamando por vidas que se foram, é a expressão de uma dor coletiva". 26

Os casos aqui apresentados são apenas exemplos de vastidão de outros "circuitos da dor" espalhados, principalmente pelas grandes cidades brasileiras e que merecem ser tratadas

\footnotetext{
${ }^{24}$ INSTITUTO do Patrimônio Histórico e Artístico Nacional. Inventário Nacional de Referências Culturais INRC: Manual de Aplicação. Brasília: IPHAN, 2000, p. 32.

${ }^{25}$ CASTRIOTA, Leonardo. Lidando com um patrimônio sensível. O caso de Bento Rodrigues, Mariana MG. Arquitextos, São Paulo, ano 20, n. 230.00, jul. 2019.

26 BRISO, C., RIBEIRO, G., GOULART, G. Dor coletiva é expressa em grafites nos muros da cidade. 0 Globo. (Site). Publicado em: 18 abr. 2017. Disponível em: https://oglobo.globo.com/rio/dor-coletivaexpressa-em-grafites-nos-muros-da-cidade-21221408. Último acesso em: 02 de jan. de 2020.
} 
como parte de uma memória, não de exaltação a violência, mas de resiliência, as mazelas cotidianas e de reconhecimento das manifestações populares que criam espaços urbanos com significados e valores próprios diante da realidade e dos problemas contemporâneos.

\section{Breves análises filosóficas}

Conforme se leu nos argumentos até aqui expostos, há um tipo de mnemotécnica para os ausentes, no contexto de traumas sociais e sua posterior ressignificação pela intervenção urbana. O retórico da Roma Antiga, Cícero, segundo a historiadora alemã Aleida Assman, foi o primeiro a sistematizar, distinguir e observar as diferenças entre dois tipos de memória: uma enquanto repositório, isto é, uma técnica de entrada e saída de dados/referências de acontecimentos; ${ }^{27}$ e a outra enquanto potência e criação de afetos:

Como peças de construção da arte da memória, ele determinou figuras e lugares (imagines et $l o c i$ ), sendo que as figuras eram úteis para a fixação afetiva de determinados conteúdos do saber, e os lugares, para a ordenação desses conteúdos e sua recuperação. O próprio Cícero cumpriu a passagem dos lugares da memória para os locais da recordação quando descobriu, segundo sua própria experiência, que as impressões captadas em um cenário histórico são "mais vivas e atenciosas" que outras assimiladas por ouvir falar ou pela leitura. ${ }^{28}$

Assim e de certa maneira, os grafites, esculturas e demais tipos de intervenções urbanas, tem uma função social que extravasa o círculo ao qual está inserida, qual seja, o ambiente familiar próximo ao homenageado (já comentado anteriormente) para o contexto que transita entre o da mera contemplação estética, nunca desligada completamente de contextos variados, quanto para o de um signo funerário de evocação de lembranças. Quanto aos signos:

são assim dados em troca do nada segundo uma lei de compensação ilusória pela qual quanto mais signos temos mais existe o ser e menos o nada. Graças à alquimia das palavras, dos gestos, das imagens ou monumentos - posto que as sepulturas seguem a mesma lógica - dá-se a transformação do nada em algo ou em alguém, do vazio num reino. ${ }^{29}$

Por isso que amigos se reúnem e tem o morto em boa conta: o guardam, armazenam, para poderem justamente "re-cordar". Essa palavra indica retirar do coração e trazer à lembrança. Mas como só este ato volitivo não basta, os entes queridos buscam para sua memória particular um local coletivo para que outros saibam, acentuando a importância de uma ausência, onde se acrescenta:

\footnotetext{
${ }^{27}$ Espécie de circuito informacional, com a imputação, processamento e depuração dos dados, permitindo os usos conceituais comunicológicos do filósofo Vilém Flusser. Cf.: FLUSSER, Vilém. Comunicologia... Op. cit.

${ }^{28}$ ASSMANN, Aleida. Espaços da recordação: formas e transformações da memória cultural. Campinas, SP: Ed. Unicamp, 2011, p. 318.

${ }^{29}$ CATROGA, Fernando. O culto dos mortos... Op. cit., p. 168.
} 
Se habitássemos ainda nossa memória, não teríamos necessidade de lhe consagrar lugares. [...] Cada gesto, até o mais cotidiano, seria vivido como uma repetição religiosa daquilo que sempre se fez, numa identificação carnal do ato e do sentido. ${ }^{30}$

Ou ainda, "a memória instala a lembrança no sagrado [...]. A memória se enraíza no concreto, no espaço, no gesto, na imagem, no objeto. [...] lugares onde ancorar sua memória". ${ }^{31}$

Se ao cemitério - com seus túmulos, lápides, monumentos e afins; sema - competia a particular guarda dessa memória do ausente para os ritos particulares da comunidade, em que o falecido se encontrava inserido, parece agora que aqueles sema estão sendo deslocados para outro espaço, mais público e movimentado, objetivando uma ausência mais presentificada (ou pré-santificada) e, portanto, coletiva.

Por sema, palavra grega, nos remetemos à seguinte explicação de Catroga, segundo a qual "todo o signo funerário, explícita ou implicitamente, remete para o túmulo (recorde-se que signo deriva de sema, pedra tumular)", pois "os objectos cemiteriais não são psicologicamente dissociáveis da estrutura em que se integram e do horizonte de crença e de sentimentos com que são lidos". ${ }^{32}$

Se esse sema encontra-se atrelada ao espaço (topos), indo do estático de uma necrópole para a dinâmica da cidade dos vivos, haverá então uma ressignificação dos locais com seus marcos memoriais ou, no mais extremo limite, a linha entre os vivos e mortos ficará borrada, onde tudo será pontilhado por certo vínculo entre a morte e a sua recordação, "isto é, o lugar (topos) e o signo (sema) estão de tal modo imbricados um no outro, são de tal modo compreendidos como coextensivos, que nenhum dos dois é fenomenologicamente separável, parecendo ser natural a relação entre o significante, o significado e o referente (ausente)" ${ }^{33}$

Embora a passagem em questão fale do ambiente cemiterial, a mesma estrutura argumentativa aplica-se ao arranjo destes novos espaços, para os novos tipos de cultos aos mortos. Pois com essa linha de raciocínio é possível depreender que "esta naturalidade recobre-se de sacralidade, já que, como lugares de consagração e de comemoração, neles se convoca o invisível através do visível e se produz atração e medo" ${ }^{34}$

Quanto a esse aspecto social, de referências memoriais pela cidade, recorta-se o seguinte trecho do texto de Pierre Nora, sem distanciá-lo muito de seu contexto original, em que diz que "são os marcos testemunhais de outra era, das ilusões de eternidade. Daí o aspecto nostálgico desses empreendimentos de piedade, patéticos e glaciais. São os rituais de uma sociedade sem ritual; sacralizações passageiras numa sociedade que dessacraliza", pois afinal são "fidelidades particulares de uma sociedade que aplaina os particularismos; diferenciações efetivas numa sociedade que nivela por princípio; sinais de reconhecimento e de

\footnotetext{
${ }^{30}$ NORA, Pierre. Entre Memória e História... Op. cit., p. 8.

31 Ibidem, p. 9.

32 CATROGA, Fernando. O culto dos mortos... Op. cit., p. 168. Sema: Signo funerário ou de referencial tanatológico, que diz respeito à morte, utilizado no texto como a menor unidade testemunhal, isto é, que contém alguma informação sobre algo.

${ }^{33}$ Ibidem, p. 172.

${ }^{34}$ Idem.
} 
pertencimento de grupo numa sociedade que só tende a reconhecer indivíduos iguais e idênticos". ${ }^{35}$

Há, portanto, uma comunicação do lugar (topos) com o testemunho/informação (sema), no que concerne à sua escolha, isto é:

- Para Ana Carolina o local escolhido foi a esquina da maternidade-escola. Deduz-se essa escolha por ter sido ali onde ela recebeu os primeiros socorros e por ser próximo de onde ocorreu o crime;

- Para Gabriel Marighetti, por sua vez, deduz-se que o muro foi escolhido por ser próximo de onde ele foi assassinado: do outro lado da calçada (onde há mesas de damas) em que ele estava com seus amigos. Acrescente-se a isso as lembranças particulares de um dos autores, pois nos anos 2000 era muito comum ver menores de idade dormindo e cheirando cola próximo ao muro grafitado;

- Para Miguel Ayoub escolheram a pilastra onde ele caiu ensanguentado, após receber o tiro. Isso é confirmado através das notícias conferidas.

Há nesses espaços de transmutação de dores extremas, um esforço autônomo de grupos sociais, em geral familiares, vizinhos e amigos das vítimas, em torná-los em lugares. Os espaços significados por uma comunidade local, nos termos, tanto do que define a noção de Lugar no INRC, acima citado, quanto no sentido daquilo que Basso chama "senses of places", ou seja, um lugar significado pela experiência acumulada culturalmente por uma coletividade, bem como a forma como o lugar é vivido pelo próprio indivíduo e que imprime nos lugares suas próprias experiências de vida e as histórias do grupo no qual se insere. ${ }^{36}$

Cabe considerar ainda se, somente para eventos criminosos, valorados como trágicos ou que se entendam como crime, que as homenagens das mais diversas expressões artísticas, coincidem entre o local escolhido e o local do crime? ou seria mera junção ao acaso do sema e topos, signo funerário? visto que, a título de complicação, outros mortos retratados em grafites foram representados em locais distantes do acontecimento criminoso, dissociando dessa maneira o lugar do acontecimento da morte com o de sua homenagem, como no caso do menino Eduardo Jesus Ferreira, em que apenas o seu nome figura em um muro na avenida Pasteur, embora na sua comunidade, no Morro do Alemão, tenham ressignificado uma rua com o seu nome. Ou então do policial Caio Robinson da Silva Lins, assassinado no morro do São Carlos, no Estácio, mas cujo grafite em sua homenagem encontra-se no muro de sua antiga residência. Cabe a observação, ainda, do marco memorial na Lagoa para os policiais mortos (em serviço ou não), e crianças mortas vítimas do confronto entre as forças do Estado e seus algozes, pois tanto para um lado quanto para o outro, há placas com breves dizeres, ressaltando o aspecto violento de cada vida ceifada à bala, encontrando-se distante espacialmente do ponto da ruptura violenta.

\footnotetext{
35 NORA, Pierre. Entre Memória e História... Op. cit., p. 13.

36 BASSO, Keith H. Wisdom Sits in Places: Landscape and Language Among the Western Apache. Albuquerque: University of New Mexico Press, 1996. Distinguindo-se, assim, através da subjetividade imputada, o termo "espaço" do termo "lugar".
} 
As reflexões acima lançam luz também sobre inúmeras outras questões como a criação de falso histórico, dissociação de espaço-memória, memória seletiva e tantas outras que ficam apenas como indicativos para futuras pesquisas. ${ }^{37}$

Por fim, um parágrafo à parte volta-se ao violento episódio que ceifou a vida da vereadora Marielle e do motorista Anderson. Sua grata e fortíssima memória pesa a muitos. 0 muro na parte de trás do hospital da Polícia Civil do Rio de Janeiro, no bairro carioca do Estácio, recebeu de maneira espontânea as mais diversas formas de homenagens, dentre as quais: velas, flores, faixas, grafites e demais manifestações gráficas, como frases de ordem e estênceis. Saindo deste lugar, outros pontos da cidade receberam outros tantos grafites contendo-Ihe o rosto ou o corpo, e dizeres de resistências às quais as ações políticas da vereadora eram dedicadas. ${ }^{38}$ Alçou-se assim sua imagem a uma fama, glória, que permite efetivamente a vida eterna, perpetuação e principalmente, memória enquanto potência política. A cidade tem sido o lugar de expressão de tal potência. "Os lugares de memória são, antes de tudo, restos". ${ }^{39}$

\section{Considerações finais}

Pode-se dizer que o "circuito da dor" enquanto espaço dos memoriais aqui abordados e que vão se criando orgânica e espontaneamente num pequeno espaço da grande metrópole, é um espaço de vivência, tanto do luto, da memória de dor que busca algum tipo de resolução, quanto também do grito emocionado desses grupos sociais pela almejada paz. É, também, uma forma de resistência à frieza insensível de uma cidade rasgada por anti-monumentos rodoviários e cada vez menos aberta à criação e manutenção de espaços para as escalas da convivência humana. Além de um espaço de resiliência, uma forma de ressignifcar a dor e partilhar o sentimento de perda numa perspectiva coletiva abraçada e valorada por muitos que se sentem afetados de alguma maneira, seja pela arte, seja pela dor da ausência ou da brutalidade do crime.

Nesse sentido a proposta aqui é antes de mais uma iniciativa de lançar luz sobre cantos escuros, sugerindo-os como possíveis candidatos ao acautelamento que deve ser encarado pelas instituições de preservação do patrimônio cultural numa forma de apreender e lidar com esse tipo de patrimônio sensível, tão presente nas zonas urbanas.

\footnotetext{
37 Respectivamente: XAVIER, Janaína; et al. O princípio de falso histórico brandiano aplicado na demolição e reconstrução do patrimônio ferroviário de Artur Nogueira. Anais do 30 Simpósio Científico do ICOMOS Brasil. Belo Horizonte, MG: Even3, 2019; VIEIRA, Sidney Gonçalves. Cidade, memória e hipermodernidade: apontamento para enteder a cidade contemporânea. In: KNACK, Eduardo. R. J.; FERREIRA, Maria L. M.; POLONI, Rita J. S. (orgs.). Memória \& Patrimônio - Temas e Debates. Porto Alegre: Editora FI, 2018; VEIGA, Edison. Memória Seletiva, patrimônio sucateado. Estadão. (Site). Publicado em: 8 nov. 2015. Desponível em: https://sao-paulo.estadao.com.br/blogs/edisonveiga/memoria-seletiva-patrimonio-sucateado/. Acesso em: 09 maio 2020.

38 Cf.: Marielle - Homenagens. Composição de Hércules da S. X. Ferreira. Google Maps. (Plataforma Eletrônica). Disponível em: https://tinyurl.com/memoriamarielle. Acesso em: ago. 2019.

39 NORA, Pierre. Entre Memória e História... Op. cit., p. 12.
} 


\section{Referências}

\section{Fontes}

\section{Mapas}

Espaços de Recordação - RUPTURAS. Google Maps. (Plataforma Eletrônica). Disponível em: http://tinyurl.com/rupturas. Acesso em: Acesso em: ago. 2019.

Marielle - Homenagens. Composição de Hércules da S. X. Ferreira. Google Maps. (Plataforma Eletrônica). Disponível em: https://tinyurl.com/memoriamarielle. Acesso em: ago. 2019.

\section{Legislação}

RIO DE JANEIRO. Lei Municipal n.o 3.239, de 12 de junho de 2001. Dá o nome de Espaço Pela Paz - Ana Carolina da Costa Lino, à área embaixo do viaduto formado pela pista de acesso ao Túnel Santa Bárbara, na Rua das Laranjeiras e dá outras providências. Rio de Janeiro, 2001.

\section{Obras de Referência}

INSTITUTO do Patrimônio Histórico e Artístico Nacional. Inventário Nacional de Referências Culturais - INRC: Manual de Aplicação. Brasília: IPHAN, 2000.

SILVA, Raul Mendes. Djanira. (Verbete). Dicionário de Artistas do Brasil. (Recurso Eletrônico). Disponível em: http://www.raulmendessilva.com.br/brasilarte/nacional/primeira.html. Acesso em: 10 jan. 2020.

\section{Matérias Publicadas em Jornais e Revistas}

ALVES, Raoni. Grafite em homenagem a Marielle feito por Malala Yousafzai é vandalizado no Rio G1. (Site). Publicado em: $18 \mathrm{dez}$. 2018. Disponível em: https://g1.globo.com/rj/rio-dejaneiro/noticia/2018/12/18/grafite-em-homenagem-a-marielle-feito-por-malala-yousafzai-evandalizado-no-rio.ghtml. Acesso em: 10 jan. 2020.

BRISO, C., RIBEIRO, G., GOULART, G. Dor coletiva é expressa em grafites nos muros da cidade. $O$ Globo. (Site). Publicado em: 18 abr. 2017. Disponível em: https://oglobo.globo.com/rio/dor-coletiva-expressa-em-grafites-nos-muros-da-cidade21221408. Último acesso em: 02 de jan. de 2020.

CAPELLI, Paulo. Deputado que quebrou placa com nome de Marielle emoldurou fragmento e botou na parede. Extra. (Site). Publicado em: $14 \mathrm{fev}$. 19. Disponível em: https://extra.globo.com/noticias/rio/deputado-que-quebrou-placa-com-nome-de-marielleemoldurou-fragmento-botou-na-parede-23453055.html. Acesso em: ago. 2019.

MORAES, Sérgio. "Quem mandou matar Marielle?": o clamor que despertou pelo Brasil. El País. (Site). Publicado em: 16 mar. 2019. Disponível em: https://brasil.elpais.com/brasil/2019/03/16/politica/1552740136_102710.html. Acesso em: 10 jan. 2020.

MORAES, Sérgio. A duas semanas de deixar PGR, Raquel Dodge estuda federalização do caso Marielle. El País. (Site). Publicado em: 12 mar. 2019. Disponível em: https://brasil.elpais.com/brasil/2019/09/04/politica/1567563791_734607.html. Acesso em: 10 jan. 2020.

PAIVA, Vitor. Artista expõe o desrespeito de selfies tiradas por turistas no Memorial do Holocausto. Hypeness. (Site). Publicado em: jan. 2017. Disponível em: 
https://www.hypeness.com.br/2017/01/artista-expoe-o-comportamento-contraditorio-deturistas-no-memorial-do-holocausto/. Acesso em: 10 jan. 2020.

TORRES, Sérgio. Estudante é morta a tiros de fuzil no Rio. Folha de São Paulo. (Site). Publicado em: 16 abr. 1998. Disponível em: https://www1.folha.uol.com.br/fsp/cotidian/ff16049827.htm. Acesso em: 10 jan. 2020.

VEIGA, Edison. Memória Seletiva, patrimônio sucateado. Estadão. (Site). Publicado em: 8 nov. 2015. Desponível em: https://sao-paulo.estadao.com.br/blogs/edison-veiga/memoria-seletivapatrimonio-sucateado/. Acesso em: 09 maio 2020.

ZUAZO, P. "Queria ter um neto", diz pai no enterro de jovem assassinado em Laranjeiras. Extra. (Site). Publicado em: 16 abr. 2017. Disponível em: https://extra.globo.com/casos-depolicia/queria-ter-um-neto-diz-pai-no-enterro-de-jovem-assassinado-em-laranjeiras21215265.html. Acesso em: 10 abr. 2018.

\section{Bibliografia}

ADORNO, Theodor W. Industria cultural e sociedade. São Paulo: Paz e Terra, 2002; BENJAMIN, Walter. A obra de arte na era de sua reprodutibilidade técnica. In: Obras escolhidas I. São Paulo: Brasiliense, 1987.

ASSMANN, Aleida. Espaços da recordação: formas e transformações da memória cultural. Campinas, SP: Ed. Unicamp, 2011.

BARROS, Anna. Espaço, lugar e local. Revista USP, São Paulo, n. 40, p. 32-45, fev. 1999.

BASSO, Keith H. Wisdom Sits in Places: Landscape and Language Among the Western Apache. Albuquerque: University of New Mexico Press, 1996.

BENJAMIN, Walter. A obra de arte na era de sua reprodutibilidade técnica. In: Obras escolhidas I. São Paulo: Brasiliense, 1987.

BINFORD, S. R. A structural comparison of disposal of the dead in the Mousterian and the Upper Paleolithic. Southwestern Journal of Anthropology, v. 24, n. 2, 139-154, Summer 1968.

CARVALHO, Ronaldo Cerqueira. Rio de Janeiro - uma cidade conectada por túneis. Instituto Pereira Passos - Armazém de DADOS, Rio de Janeiro, v. 4, p. 1-57, 2004.

CASTRIOTA, Leonardo. Lidando com um patrimônio sensível. O caso de Bento Rodrigues, Mariana MG. Arquitextos, São Paulo, ano 20, n. 230.00, jul. 2019.

CATROGA, Fernando. O culto dos mortos como uma poética da ausência. ArtCultura, Uberlândia, v. 12, n. 20, p. 163-182, jan.-jun. 2010.

FERREIRA, Soraya Venegas; ARCO, Débora Galeano. De pichação à manifestação artística: Um estudo dos graffitis de ACME 23 no âmbito da folkcomunicação. Revista Internacional de Folkcomunicação, v. 12, p. 55-73, 2014.

FLUSSER, Vilém. Comunicologia: reflexões sobre o futuro: as conferências de Bochum. São Paulo: Martins Fontes, 2014.

NORA, Pierre. Entre Memória e História: a Problemática dos Lugares. Projeto História: Revista do Programa de Estudos Pós-Graduados de História, São Paulo, v. 10, p. 7-28, out. 2012.

SOTRATTI, Marcelo Antonio. A ideologia espacial na patrimonialização e gestão de bens culturais em áreas gentrificadas. Boletim Campineiro de Geografia, Campinas (SP), v. 6, p. 303-323, 2016. 
VIEIRA, Sidney Gonçalves. Cidade, memória e hipermodernidade: apontamento para enteder a cidade contemporânea. In: KNACK, Eduardo. R. J.; FERREIRA, Maria L. M.; POLONI, Rita J. S. (orgs.). Memória \& Patrimônio - Temas e Debates. Porto Alegre: Editora FI, 2018.

XAVIER, Janaína; et al. O princípio de falso histórico brandiano aplicado na demolição e reconstrução do patrimônio ferroviário de Artur Nogueira. Anais do 30 Simpósio Científico do ICOMOS Brasil. Belo Horizonte, MG: Even3, 2019. 